\title{
Od umjetnosti riječi do 9. umjetnosti: Vidimo se tamo gore, roman i strip
}

\section{Abstract: From the Art of Words to Ninth Art: See You Up There, Novel and Comic Book}

Along with the introductory remarks on the relationship between novels and comics and their historically problematic status, this paper analyzes and interprets, from the perspective of creation, i.e. the scriptwriter and the illustrator, as well as from the perspective of the reception or audience, the procedures by which Pierre Lemaitre's novel Goodbye, Up There is, on the level of content and expression, transformed into the new medium of comics. The comparative narrative analysis of the novel and the comic book shows that the shift from telling to showing mode requires, above all, dramatization, introduction of dialogues, and certain alterations of the plot, focalization, themes, and motivation of characters. These alterations can be linked by the common denominator adaptation. Adaptation is thus seen as the creative process of transcoding, where the original is reconceived and reinvented in another form of expression, as well as an intertextual process of reception as decoding the narrative.

Keywords: novel, comic book, narrative, adaptation, transcoding, reinterpretation

\section{Uvod}

Sintagma čitanje romana sedamdesetih se i osamdesetih godina 20. stoljeća u hrvatskom jeziku među mlađom populacijom koristila kao istoznačnica za čitanje stripa. Naime, stripovi, odnosno crtani romani, povezivali su se s pisanim romanima, prema Hrvatskoj enciklopediji „srodnom trivijalnom rotoliteraturom na kioscima.“ („Strip“) Već se stoga donekle uobičajilo, s obzirom na ovu srodnost, teorijske rasprave o stripu početi osvrtom na njegovu dugu, ali i statusno problematičnu 
povijest. A povijest stripa, baš kao i povijest romana, seže još u stari vijek. Poznato je kako se roman pojavio u Grčkoj gdje su i utemeljene prve zakonitosti vrste. Začetke, odnosno preteče stripa pronalazimo pak u Mezopotamiji, Egiptu, Grčkoj i Rimu, no naviještale su ga već i slikarije u pretpovijesnim spiljama. Kao i roman, i strip je u prošlosti, i to ne tako dalekoj, smatran bastardom, prezrenom, manje vrijednom vrstom, križancem plemenitijih roditelja. Obezvređivanje romana tijekom stoljeća prišivanjem mu etikete književnosti za žene i šund literature u nastavcima usporedivo je s prezrenošću stripa kao zabave za djecu i slabo obrazovan te se odnosi kako na sadržaj i njegovu prezentaciju tako i na publiku kojoj je namijenjen. Problem proizlazi, kako sažimlje Peeters (6), iz brkanja te stavljanja znaka jednakosti između medija i žanra, jer je propitivanje i vrednovanje nastalih produkcija zapravo posve neupitan postupak. Ukratko, niti su svi romani, niti su svi stripovi remek-djela, ali neki nedvojbeno jesu.

\subsection{Poetike}

Duga praksa postojanja tehnika i elemenata koje sačinjavaju i određuju iskazivanje u romanu i stripu okrunjena je naknadnom pojavom poetika, štoviše čak stoljećima kasnije nakon prvog pojavljivanja vrsta. Budući da je poetika neraskidivo vezana uz pretpostavku postojanja teorijske svijesti o praksi određene književne vrste, najstarije se poetike romana pojavljuju u 17. stoljeću, čak tisuću petsto godina nakon prvog procvata vrste (Žmegač 9). Suvremeni se strip javlja u 19. stoljeću, a svoj procvat doživljava u 20. stoljeću koje se naziva i stoljećem stripa (Munitić 11). Evoluiranje vrste odvija se usporedo s promišljanjima teorijske prirode i uspostavom u hodu, najčešće metodom pokušaja i pogrešaka, takozvane „gramatike“ medija (Peeters 12) kao niza zakonitosti na kojima počiva umjetnost stripa.

lako najčešće manjkave i dvojbene, definicije romana u načelu se slažu kako je riječ o pripovjednom tekstu (fr. récit), odnosno narativu fiktivnog karaktera. Temeljnu tehniku romana predstavlja pripovijedanje, a roman općenito ima fabulu ili radnju koja teče te likove. I strip je po svojoj definiciji récit, međutim nije „pripovjedni tekst“ u doslovnom značenju ove sintagme na hrvatskom jeziku jer tekst predstavlja (ali čak niti ne nužno) samo jednu od njegovih komponenti. Dok je roman kazivački, strip je prikazivački medij. Strip je jedan od oblika narativa u slikama, récit en images (Groensteen, La Bande dessinée 44). U skladu s tehnikom grafičkog izražavanja priča 
je u stripu ispričana kroz crteže koji se logički nižu. Ta se figurativna naracija temelji na prikazivanju radnje u sekvencama, u svojim najvažnijim etapama unutar kvadrata(-slike) ili vinjete. Stripovski kvadrati slijede jedan za drugim, nastavljaju se na onaj prethodni, ulančavaju se i u tom smislu samo su fragmenti jedne veće cjeline, a svaki je od njih sâm po sebi nepotpun. Često su i elastični te funkcioniraju u peripolju s ostalim kvadratima iste table ili ploče, odnosno kvadrat ne funkcionira samostalno i neovisno o ostalim kvadratima koji ga okružuju (Peeters 21). Narativni kontinuitet stripa počiva dakle upravo na povezanosti kvadrata. Što se pak njegove tekstualne komponente tiče, riječi i zvukovi podliježu zakonitosti upisivanja u balončiće ili filaktere različita oblika koji su organski dio stripa. Intermedijalnost fenomena kao suodnos zasebnih medija nameće se već ocu suvremenog stripa Töpfferu koji napominje da bi „[c]rteži, bez teksta, imali ... samo nekakvo nejasno značenje, a tekst bez crteža ne bi značio ništa. Vrsta romana koju oni zajedno tvore utoliko je originalnija ukoliko najviše nalikuje upravo samom romanu." (Delobbe 5) Strip kombinira dva konvencionalno različita medija integrirajući ih u svoje sastavnice čime nastaje jedan novi medij (Rajewsky 51-52), dolazi do fuzije, spajanja različitih medija u jedan nadmedij, intermedij koji je više od pukog zbroja svojih pojedinih dijelova (Schröter 2). Drugim riječima: Bez kompleksa pred težinom bilo kojeg prikazivačkog zadatka, od najkonkretnijeg do sasvim apstraktnog, strip tako stvara svoj miješani jezik, miješani komunikacijski kodeks, sintezu u kojoj se pojavljuju elementi mnogih drugih jezika i kodeksa komunikacije - od napisane i oslikovljene riječi, preko slikovnih, piktografskih i signalističkih vrijednosti, sve do oslikovljenog zvuka, pokreta, emocije, osjeta, psihološkog stanja itd. (Munitić 36)

\section{Vidimo se tamo gore, roman i strip}

Pierre Lemaitre suvremeni je francuski književnik, rođen 1951, koji je spisateljsku karijeru započeo relativno kasno, 2006. godine, objavivši svoj prvi roman Travail soigné. Ubrzo se renomira kao autor kriminalističkih romana. Godine 2013. objavljuje roman Au revoir là-haut, u hrvatskom prijevodu Vidimo se tamo gore (2015) ${ }^{[1]}$ U romanu koji će iste godine dobiti poznatu francusku književnu nagradu Goncourt djelomice se odmiče od žanra koji ga je proslavio prema žanru povijesnog romana. Kako piše na koricama hrvatskog izdanja ovog romana „Radnja se, ... vrti oko malverzacija tijelima preminulih i trgovanja osjećajem nacionalnog ponosa, no umjesto turobnog i 
mučnog dokumentarizma, Lemaitreov roman je vitalistička satira koja slavi stvaralačku maštu i njezinu sposobnost da nadjača fantome 'nacije', 'kapitala' i 'plemenita roda', makar u toj borbi bila zastrašujuće osakaćena." Roman, zapravo, obrađuje staru i rekurentnu temu francuske književnosti, temu živih mrtvaca, ratnih veterana koji se vraćaju s bojišta na kojem su i fizički i emocionalno osakaćeni. U ovom su slučaju glavni likovi dvojica antijunaka, Albert Maillard i Edourd Péricourt, čiji problemi osobnosti počinju već ranije, u djetinjstvu. Obojica su naime kao djeca ostali bez jednog roditelja, a s drugim imaju težak odnos, Albert s majkom, a Edouard s ocem. Roditelji ne razumiju senzibilitet i interese svoje djece, smatraju kako su iznevjerila očekivanja te konstantno obezvređuju njihova postignuća. Pod teretom majčinih kritika Albert izrasta u osobu bez imalo samopouzdanja i samopoštovanja, odraslu osobu sa strahovima djeteta koja nekontrolirano mokri, kojoj je, da bi izašla iz svoja četiri zida, potreban prijelazni objekt. I dok je Albert postao povučeni i plašljivi odrasli čovjek, Edouard, suočen sa stalnim očevim neodobravanjem i hladnoćom, izrasta u ekscentričnu osobu sklonu provokacijama i rizičnim ponašanjima. Roman započinje svojevrsnim prologom, zbivanjima posljednjih dana Prvog svjetskog rata. Uz likove Alberta i Edouarda tu se pojavljuje i lik natporučnika d'Aulney-Pradellea, ratnog junaka, zapravo, pokazat će se u nastavku romana, antipoda dvojice glavnih likova. Tijekom napada na Nijemce Edouard spašava Alberta, ali pritom biva ranjen i postaje „čovjek bez lica“ ( VSTG 296; ARLH 408). Nakon ovog uvodnog dijela romana radnja dalje teče linearno. Po demobilizaciji Albert osjeća moralnu obvezu skrbiti o Edouardu te se razvija odnos u kojem će se njih dvojica u međusobnoj brizi izmjenjivati u ulozi roditelja i djeteta. Dvojica antijunaka s bojišta, $\mathrm{k}$ tome i ekonomski uništeni, pokušavaju se snaći i preživjeti na bojišnici života. Početno dominantno povijesni roman počinje se postupno profilirati u kriminalistički, s dobrim i lošim lopovima u glavnim ulogama. Kroz dramsku strukturu fabule napetost raste, a čitatelj se počinje solidarizirati s lošim momcima želeći im da u svojem pothvatu uspiju i ne budu uhvaćeni.

Dvije godine nakon romana u Francuskoj je objavljen istoimeni strip, a na njegovim prvim stranicama stoji paratekstualna napomena kako je riječ o „adaptaciji romana Pierrea Lemaitrea“. Lemaitre je potpisan kao scenarist, a Christian De Metter kao crtač ovoga stripa. Pierre Lemaitre na istom se mjestu zahvaljuje crtaču što ga je uveo u tajne zanata. Priča iz romana postaje svojevrsnim predloškom za strip, uz nužne, medijem uvjetovane preinake jer „[s]vaki medij ima 
svoje iskazne mogućnosti i posebne sklopove kojima se tvori specifičan sadržaj njihovih znakova. Jasno se pokazuje da izraz uvjetuje svoj sadržaj, kao što sadržaj zahtijeva odgovarajući mu izričaj." (Peleš 26) Ista se priča odnosno događajni slijed priča u dva različita medija. Ovdje je riječ o onome što se naziva medijskom transpozicijom (Rajewsky 51), odnosno o transformaciji jedne medijske produkcije u drugu. Adaptacija kao transpozicija nastala transkodiranjem ne iscrpljuje se međutim u tome da kao formalna tvorevina ili produkcija tek vjerno reproducira, odnosno kopira svoj predložak, već je treba promatrati i šire, kao stvaralački proces - (re-)interpretaciju i (re)kreaciju, ali i kao intertekstualni proces recepcije (Hutcheon 7,8). Uži predmet raščlambe bit će, precizirajmo, početak romana i početak istoimenog stripa te posebnosti narativa i njihovo transkodiranje za potrebe drugog medija. Naime, početak narativa u pravilu ima dvostruku zadaću, ponajprije informirati, a potom zainteresirati (potencijalnog) čitatelja, pa se tako na njegovu početku pojavljuju odgovori na tri temeljna pitanja - tko, gdje i kada, odnosno obavijesti o likovima, mjestu i vremenu radnje (Jouve 18-19). Nadalje, uvod mora potaknuti čitateljevu znatiželju upotrebom različitih pripovjednih strategija. Na početku romana i stripa Vidimo se tamo gore pojavljuju se i karakteriziraju glavni likovi te postavlja prostorno-vremenski okvir fabule, uz najavu ključnih tema i motiva te pripovjednih postupaka. Kako adaptacija kao proces nužno mora voditi računa o načinu na koji se medij povezuje sa svojim primateljima, u dijelu ovoga rada koji slijedi, stavljanjem u suodnos romanesknog izvornika i novonastalog stripa te raščlanjivanjem mjesta dodira i razlike dvaju iskaznih sustava, kazivačkog i prikazivačkog, naglasak će biti stavljen upravo na taj intermedijalni stvaralački proces. Naime, uvodni dijelovi romana i stripa pritom su egzemplarni upravo zbog upotrebljenih prosedea interpretativne i kreativne prilagodbe prikazivanja radnje kroz sekvence kvadrata-slike, kraćenja fabule kao i invencije dijaloga i spajanja triju različitih očišta i pripovjedačke pozicije.

\subsection{Roman}

Roman Vidimo se tamo gore započinje scenom na bojištu posljednjih dana Prvog svjetskog rata. Može se zapravo govoriti o prvom makrosegmentu fabule, a za potrebe ovog rada nazvati ga „bojno polje 2. studenog 1918“ i označiti s A. Njega je nadalje moguće podijeliti na tri segmenta koji odgovaraju prvim trima poglavljima: segment A1, 1. poglavlje - Albert Maillard na bojnom polju 2. 
studenog 1918, segment A2, 2. poglavlje - natporučnik d'Aulney-Pradelle na bojnom polju 2.

studenog 1918. i segment A3, 3. poglavlje - Edouard Péricourt na bojnom polju 2. studenog 1918. Unutar svakog od tih segmenata nižu se mikrosegmenti. Bit će prikazani tablično, pri čemu će biti označeni malim slovima abecede koja ukazuju na njihov redoslijed, uz oznake 0 za razinu temeljne priče, - analepsu, a + prolepsu. Tablični prikaz bio bi stoga sljedeći:Tablica 1 Makrosegment fabule A - bojno polje 2. studenog 1918.

\begin{tabular}{|c|c|c|}
\hline $\begin{array}{l}\text { A1: 1. poglavlje - Albert Maillard na bojnom polju } \\
\text { 2. studenog } 1918 \text {. }\end{array}$ & $\begin{array}{l}\text { A2: 2. poglavlje - natporučnik d'Aulney-Pradelle na } \\
\text { bojnom polju } 2 \text {. studenog } 1918 .\end{array}$ & $\begin{array}{l}\text { A3: 3. poglavlje - Edouard Péricourt na bojnom } \\
\text { polju 2. studenog } 1918 .\end{array}$ \\
\hline A1a0 približavanje kraja rata & A2a0 osobnost natporučnika Pradellea & A3a0 Péricourt je ranjen u nogu \\
\hline A1b0 natporučnik Pradelle & A2b- obiteljska povijest Pradellea i fizički opis & A3b- opis Edouarda Péricourta \\
\hline $\begin{array}{l}\text { A1c0 slanje Thérieuxa i Grisonniera u izvidnicu i } \\
\text { njihova smrt }\end{array}$ & A2c- organizacija napada na kotu 113 & $\begin{array}{l}\text { A3c0 Péricourt nastoji zaustaviti krvarenje i spasiti } \\
\text { se }\end{array}$ \\
\hline A1d0 početak napada & $\begin{array}{l}\text { A2d0 Pradelle sudjeluje u napadu: } \\
\text { A2d I. Pradelle ostaje otraga; II. Pradelle vidi } \\
\text { Maillarda uz Thérieuxa i Grisonniera; III. Pradelle } \\
\text { napada Alberta koji pada u jamu; IV. Pradelle gleda } \\
\text { Alberta u jami; V. Pradelle raznosi granatom } \\
\text { Thérieuxa i Grisonniera }\end{array}$ & A3d0 Péricourt vidi Pradellea, Pradelle odlazi \\
\hline $\begin{array}{l}\text { A1e- Albert Maillard prije rata i odnos s majkom i } \\
\text { Cécile }\end{array}$ & $\begin{array}{l}\text { A2e- Pradelle je prije dva mjeseca granatom ubio } \\
\text { skupinu njemačkih zarobljenika }\end{array}$ & $\begin{array}{l}\text { A3e0 Péricourt se povlači na laktovima i pokušava } \\
\text { spasiti }\end{array}$ \\
\hline $\begin{array}{l}\text { A1f0 napad: } \\
\text { A1f: I. izlazak vojnika iz rova; II. Péricourt je } \\
\text { ranjen; III. Albert nailazi na tijela Thérieuxa i } \\
\text { Grisonniera i metke u njihovim leđima; IV. } \\
\text { Pradellov napad na Alberta; V. Albert u blatnjavom } \\
\text { krateru i pokušaj izlaska }\end{array}$ & A2f0 Pradelle se sprema baciti granatu na Alberta & A3f0 pad granate \\
\hline A1g- Cécile, majka i Albertove ideje o dezertiranju & $\begin{array}{l}\text { A2g0 pad neprijateljske granate, zemlja prekriva } \\
\text { jamu u kojoj je Albert }\end{array}$ & $\begin{array}{l}\text { A3g0 Péricourt na mjestu gdje je stajao Pradelle } \\
\text { primjećuje vršak bajunete, shvaća da je pod } \\
\text { zemljom vojnik }\end{array}$ \\
\hline A1h0 Albert pokušava izići iz jame & A2h0 Pradelle nastavlja napad na Nijemce & $\begin{array}{l}\text { A3h0 Péricourt dolazi do tog mjesta i rukama } \\
\text { počinje kopati }\end{array}$ \\
\hline A1i0 pad granate & & A3i0 Péricourt otkopava vojnika, vojnik je mrtav \\
\hline A1j- fizički opis Alberta & & $\begin{array}{l}\text { A3j0 unatoč rani Péricourt ustaje i improvizira } \\
\text { reanimaciju }\end{array}$ \\
\hline A1k0 Albert je zatrpan zemljom & & A3k0 Albert je oživio \\
\hline $\begin{array}{l}\text { A1I0 Albertov pokušaj spasa: } \\
\text { A1I I. Albert se pokušava otkopati; II. nedostatak } \\
\text { zraka; III. konjska glava; IV. gospođa Maillard ga } \\
\text { gleda; V. Albert zove Cécile; VI. zadnji udah iz } \\
\text { konjske glave; VII. Albertova smrt }\end{array}$ & & A3I0 šrapnel pogađa Péricourta \\
\hline
\end{tabular}

Tekst romana, što je vidljivo iz priložene tablice, obilježen je u načelu homologijom. Na razini segmenata radnja ne samo da se odvija linearno nego se odvija i simultano, odnosno sva se zbivanja unutar određenog vremenskog okvira odvijaju paralelno, likovi su prisutni u isto vrijeme na istim mjestima. Nadalje, i redoslijed mikrosegmenata u narativnom tekstu ukazuje na dominantno kronološki, linearni redoslijed zbivanja. Pogledamo li ipak pomnije, određeni mikrosegmenti, i to A1g, A1j, A2b, A2d i A3b, analepse su u dijegezi, odnosno elementi za narativnu anakroniju, dok su pak mikrosegmenti A1f II-A3a, A1f III-A2d II, A1f IV-A2d III, A1i-A2g-A3f, A1k-A2g te A2d IV- 
A3d u sinkroniji. Zbivanja dakle pripadaju istom vremenskom planu, a mikrosegmenti fabule koji se ponavljaju dani su u svojoj simultanosti dok se pripovjedač pritom svaki put približava drugom liku. Naime, unutar istog vremenskog okvira više mikrosegmenata fabule odvija se istovremeno, no likovi se ne prate u kontinuitetu unutar cijelog tog vremenskog odsječka, pa bi se moglo reći da se radi o svojevrsnim elipsama u pripovijedanju - nešto se događalo, a ne zna se što, da bi se o zbivanjima napokon doznalo iz perspektive drugog lika. Primjerice, pripovjedač lik Alberta Maillarda napušta na kraju prvog segmenta fabule, točnije u mikrosegmentu A1I VII, odnosno u trenutku njegove smrti, da bi se radnja nastavila u trećem segmentu, konkretno u mikrosegmentu A3k kada ga spašava lik Péricourta. Ove elipse čimbenik su koji pridonosi ubrzanju naracije: nešto se zbiva, no pripovjedač o tome ne pripovijeda. Drugim riječima vrijeme radnje teče, ali ne i vrijeme pripovjednog teksta, događaji ne prestaju, međutim pripovjedač o njima neko vrijeme ne govori ništa, pa se upravo na ovaj način gradi napetost. Postizanju napetosti svakako doprinose i komentari pripovjedača kao anticipacije, odnosno prolepse. Naime, on višestruko iz perspektive budućnosti najavljuje zbivanja, poput: „Umrijeti posljednji, mislio je Albert, to je jednako kao i umrijeti prvi, potpuno glupo. A upravo to će se i dogoditi.“ (VSTG 13). Ili pak „A okončati živ zatrpan nadomak kraju rata, iskreno rečeno, bio bi to peh. No upravo to će se i dogoditi. Živ zatrpan, naš mali Albert." (VSTG 17) Pripovjedač je neimenovan i sveznajuć, a dominantno se pojavljuje kao „ja“ (uz, u nekoliko slučajeva, osobnu zamjenicu u prvom licu množine, „mi“). U pripovijedanju pak prevladava osobna zamjenica u trećem licu jednine „on“ koja se odnosi na likove, te, naravno, upućuje na razinu prave fikcije.

Sveznajuća perspektiva heterodijegetskom i ekstradijegetskom pripovjedaču omogućuje s jedne strane prikazivanje radnje u njezinu tijeku, a s druge, tumačenje i komentiranje te iste radnje, ponekad čak uz opaske iz vremenske perspektive budućnosti. Pripovjedač dakle pripovijeda o očito prošlim događajima, piše s odmakom od samih zbivanja, poseže za njihovim komentiranjem te se, zapravo, tako od same priče udaljava. Međutim, u tekstu romana učestalo nailazimo na preneseni i trenutačni diskurs. Podsjetimo da je, što se govora i misli likova tiče, prema naratologiji njihovo prenošenje moguće stupnjevati u rasponu od najveće distance do najveće blizine (Genette 191-94). Pri prenošenju riječi i misli likova pripovjedač im je ovdje blizak tako da ponekad postaje dvojbeno radi li se o riječima ili mislima samog lika ili pak pripovjedača, kao u sljedećem primjeru 
Albertova otkrića mrtvih tijela svojih suboraca: „Albert ne zna što mu je, možda intuicija, zgrabi starog za rame i gurne ga. Mrtvac se tromo zanjiše i ispruži potrbuške. Da bi shvatio, Albertu treba nekoliko trenutaka. Potom pogleda: kada se krećete prema neprijatelju, ne umirete pogođeni s dva metka u leđa.“ (VSTG 18) Nešto dalje u tekstu, kad Albert pada u jamu, čitamo: „Nasađen na potpetice (glinasta zemlja kliže se kao sapun), pokušava ponovo disati. U mislima, kratkim i raštrkanim, neprestano se vraća ledenom pogledu natporučnika Pradellea. ... Albert ima dojam da je prošlo dugo vremena od njegova pada. Ustvari, kolika može biti udaljenost između njih, dva metra, ne više. Manje zacijelo. No velika je tu razlika." (VSTG 19) Ovakva narativna blizina osnovica je, upravo zahvaljujući trenutačnom govoru, za izmjenu pripovjednih perspektiva. I dok je priči nadređeni pripovjedač sveznajući, obilježen nultom fokalizacijom, ona zapravo nije fiksna, nego se izmjenjuje i prelazi na ograničenu, internu fokalizaciju likova. Nadalje, prelaženje s jednog na drugi segment fabule najčešće je obilježeno početnom pripovjedačevom nultom fokalizacijom koja se potom počinje miješati s fokalizacijom lika, pri čemu se status onoga koji vidi dovodi u pitanje - više nismo sigurni vidi li i dalje pripovjedač ili pak lik. Priča se dakle u prva tri segmenta romana pripovijeda kao čitav niz različitih očišta triju likova koji sami nisu pripovjedači, a unutarnje perspektive tih likova omogućuju da se priča sagleda iz više perspektiva. Recimo i da je trenutak naracije naknadan, da se priča o događajima koji su završili i to da se pripovijeda u prošlom vremenu, međutim narativna anakronija i trenutni govor omogućuju postizanje efekta simultanosti, odnosno stvara se iluzija da pripovjedač o događajima pripovijeda u trenutku dok se odvijaju.

\subsection{Strip}

Fabula prvog makrosegmenta romana, nazvanoga A - bojno polje 2. studenog 1918, može se, temeljem podataka iz prvih triju poglavlja, rekonstruirati i sažeti na sljedeći način: dvojica francuskih vojnika, Thérieux i Grisonnier, ubijena su 2. studenog 1918. dok su bili u izvidnici. Francuski vojnici u rovovima dobivaju zapovijed da krenu u napad na Nijemce. Tijekom napada ranjen je vojnik Edouard Péricourt, a Albert Maillard nailazi na tijela ubijenih Thérieuxa i Grisonniera te vidi rane od metaka u njihovim leđima. Natporučnik Pradelle napada Maillarda koji pada u rupu od granate. Pradelle ručnom granatom raznosi tijela Thérieuxa i Grisonniera. Na isti način želi dokrajčiti Maillarda, no ovog prekriva sloj zemlje od pale neprijateljske granate. Ranjeni 
Péricourt vidi Pradellea. Maillard se, zatrpan zemljom, pokušava osloboditi. Péricourt puže prema mjestu gdje je stajao Pradelle i počinje kopati. Maillard ostaje bez zraka i umire. Péricourt uspijeva otkopati i oživjeti Maillarda. Šrapnel pogađa Péricourta.

Stavi li se u suodnos prvi makrosegment fabule romana koji obuhvaća prvih 53 od ukupno 567 stranica, što predstavlja otprilike 1/10 romana, s prvim makrosegmentom u stripu, a riječ je o 22 od ukupno 162 stranice, odnosno 1/8 stripa, ti omjeri ostaju bliski i usporedivi, bez obzira na intervencije kojima pribjegava strip jer Lemaitre i De Metter pristupaju dakako prilagođavanju fabule romana potrebama novog medija. Naime, u tekstu romana određeni se mikrosegmenti fabule ponavljaju, što ukazuje na veliku važnost repetitivnog modusa, koji pak u stripu u potpunosti izostaje. Prvi makrosegment fabule u romanu sačinjen je od triju segmenata, no u stripu radnja više nije iskazana kroz tri različita i jasno odvojena očišta kao u romanu, nego počiva upravo na sažimanju triju prvih poglavlja po načelu prikazivanja simultanosti zbivanja. Sinkronija time ovdje izrasta u temeljnu organizacijsku tehniku stripa. Fabula u stripu u glavnini ostaje ista u odnosu na roman, no ipak je ponešto preinačena: nekoliko dana prije završetka Prvog svjetskog rata natporučnik Pradelle izdaje dvojici francuskih vojnika, Thérieuxu i Grisonnieru, zapovijed da izvide što se događa u njemačkim rovovima, a vojnici su tijekom izviđanja ubijeni. Francuski vojnici u rovovima dobivaju zapovijed da krenu u napad na Nijemce. U zoru počinje napad. Tijekom napada vojnik Albert Maillard nailazi na tijela ubijenih Thérieuxa i Grisonniera, zapaža rane od metaka u njihovim leđima te shvaća Pradelleovu podvalu - vojnici su stradali od francuskih, a ne njemačkih metaka. Natporučnik Pradelle nakon toga napada Maillarda koji pada u rupu od granate. Pradelle nastavlja dalje, a Maillarda nakon eksplozije neprijateljske granate prekriva sloj zemlje. Ranjeni vojnik Péricourt vidio je da se nešto događa. Maillard se, zatrpan zemljom, pokušava osloboditi. I Péricourt počinje kopati. Maillard ostaje bez zraka i umire. Péricourt uspijeva otkopati i oživjeti Maillarda. Šrapnel pogađa Péricourta.

Konvencijama stripovskog izražavanja prilagođen je i pripovjedač. Dok u romanu dominira svojim sveznanjem, u stripu ostaje izravno prisutan tek u incipitu. Početak stripa sastoji se naime od tri vinjete većih dimenzija koje zauzimaju čitavu stranicu. Glas pripovjedača javlja se unutar recitativnog filaktera, „kocke“ (fr. pavé), u prve dvije vinjete i svega tri vrlo kratke napomene o vremenskom kontekstu zbivanja: godina „1918“, „Prvi svjetski rat...“ te „... posljednji dani.“ I dok se 
u romanu pripovjedač približava likovima trenutačnim govorom, u stripu se riječ u potpunosti prepušta likovima koji samostalno progovaraju te se u odnosu na pripovjedača osamostaljuju. Tako se već u trećoj vinjeti pojavljuju filakteri s glasovima likova, odnosno njihov dijalog koji u samom romanu ne postoji. Rečenice gotovo identičnog sadržaja pojavljuju se pak u romanu na početku 1. poglavlja, kada pripovjedač prenosi Maillardova razmišljanja kako perspektiva kraja rata ubija u pojam natporučnika Pradellea (ARLH 15; VSTG 13) te u 2. poglavlju kada pripovjedač donosi Pradelleovu ambiciju da bi u trenutku razvojačenja mogao biti u činu satnika (ARLH 39; VSTG 29). U stripu je pak riječ o dijalogu koji se odvija između Maillarda, Grisonniera i Thérieuxa iza Pradelleovih leđa (11). Da se radi upravo o trima spomenutim likovima, čitatelju postaje jasno na sljedećoj stranici kada se u razgovoru likovi imenuju, što je još jedna stripovska konvencija. $\mathrm{Na}$ toj se stranici naime nalazi dijalog Pradellea, Grisonniera i Thérieuxa te Maillarda i Grisonniera. Dijalozi odgovaraju pripovijedanju iz 1. poglavlja romana (ARLH 16-17; VSTG 13/14) u kojem Pradelle upućuje vojnike u izvidnicu, a oni se nadaju mirnom povratku u rov. Dok se u romanu ne zna zašto su poslani baš ovi vojnici, u stripu se dade zaključiti kako je riječ o svojevrsnoj kazni jer su se usudili ući u raspravu s Pradelleom. Vinjete na 13. stranici stripa prikazuju noćni izlazak Grisonniera i Thérieuxa iz rova dok ih drugi vojnici promatraju i šale se kako je riječ o sretnicima koji će putem možda naići na kakvu djevojku, što u romanu izostaje. Po izlasku iz rova Albert nailazi na ubijene Grisonniera i Thérieuxa te slijedi dijalog s Pradelleom (16), kojeg u romanu također nema - Maillardove misli koje u romanu prenosi pripovjedač u stripu se još jednom preinačuju u govor. Nadalje, na 20. stranici stripa simultano se prikazuju zatrpani Maillard kojemu se pričinjaju majčine riječi i Péricourt koji kopa te se predstavlja i obraća suborcu pod zemljom.

U stripu dakle dolazi do invencije dijaloga na temelju romanesknog predloška, što se pregledno prikazuje u sljedećoj tablici[i] :Tablica 2 Invencija dijaloga na temelju romanesknog predloška

\begin{tabular}{|l|l|}
\hline Roman & Strip \\
\hline L'idée de la fin de la guerre, le lieutenant Pradelle, ça le tuait. (15) & Maillard : La fin de la guerre, le lieutenant Pradelle, ça le tue ! \\
$\begin{array}{l}\text { Déjà, lieutenant en trois ans, ce n'était pas mal. Là-dessus, un coup d'éclat et } \\
\text { I'affaire serait entendue : capitaine à la démobilisation. (39) }\end{array}$ & $\begin{array}{l}\text { Grisonnier : Pour un héros, la fin de la guerre, c'est comme une défaite... } \\
\text { Thérieux : Oui, c'est con pour lui : un dernier exploit et il était capitaine à la } \\
\text { démobilisation... (11) }\end{array}$ \\
\hline
\end{tabular}




\begin{tabular}{|c|c|}
\hline $\begin{array}{l}\text { Un ordre était tombé d'en haut, exigeant qu'on aille surveiller de plus près ce } \\
\text { que faisaient les Boches. Il n'était pourtant pas nécessaire d'être général pour } \\
\text { se rendre compte qu'ils faisaient comme les Français, qu'ils attendaient la fin. } \\
\text { (16) } \\
\text { Pour remplir cette mission de reconnaissance, le lieutenant Pradelle choisit } \\
\text { Louis Thérieux et Gaston Grisonnier, difficile de dire pourquoi, un jeune et un } \\
\text { vieux, peut-être l'alliance de la vigueur et de l'expérience. (16) } \\
\text { Les deux soldats n'étaient d'ailleurs pas inquiets d'approcher ainsi l'ennemi. Vu } \\
\text { le statu quo des derniers jours, même s'ils les apercevaient, les Boches les } \\
\text { laisseraient regarder et s'en retourner, ca serait comme une sorte de } \\
\text { distraction. (17) }\end{array}$ & $\begin{array}{l}\text { Pradelle : Il me faut deux hommes pour aller voir ce qui se passe chez les } \\
\text { Boches ! } \\
\text { Grisonnier : Y a rien à voir ! } \\
\text { Thérieux : Les Boches, ils font comme nous, ils attendent la fin de la guerre. } \\
\text { Pradelle : Raison de plus : ce sera une promenade de santé... Allez ! Grisonnier } \\
\text { et Thérieux! } \\
\text { Maillard : Ce n'est pas de pot, hein... } \\
\text { Grisonnier : T'en fait pas, Maillard, il ne se passera rien. (12) }\end{array}$ \\
\hline- & ? : Les veinards... Ils vont peut-être tomber sur une Gretchen... (13) \\
\hline $\begin{array}{l}\text { Autour d'Albert, tout le monde en eut le souffle coupé. Puis il y eut des cris. } \\
\text { Salauds. (17) }\end{array}$ & Ils les ont descendus! Les salauds! (13) \\
\hline $\begin{array}{l}\text { Les Boches sont bien toujours pareils, quelle sale engeance ! Des barbares, } \\
\text { etc. En plus, un jeune et un vieux ! Ça ne changeait rien, mais dans l'esprit de } \\
\text { tous, les Boches ne s'étaient pas contentes de deux soldats français, avec eux, } \\
\text { ils avaient abattu deux emblèmes, bref, une vraie fureur. (17) }\end{array}$ & $\begin{array}{l}\text { Maillard : Les enfoirés ! } \\
\text { ? : 'vont pas s'en tirer comme ça... (14) }\end{array}$ \\
\hline $\begin{array}{l}\text { Il lui faut quelques secondes pour réaliser, à Albert. Puis la vérité lui saute au } \\
\text { visage : quand on avance vers l'ennemi, on ne meurt pas de deux balles dans } \\
\text { le dos. (23) } \\
\text { A quelques jours de l'armistice, les gars n'étant plus très pressés d'aller } \\
\text { chatouiller les Boches, la seule manière de les pousser à l'assaut, c'était de les } \\
\text { foutre en pétard : où était donc Pradelle lorsque les deux gars se sont fait tirer } \\
\text { dans le dos? } \\
\text { Bon Dieu... } \\
\text { Stupéfié par ce constat, Albert se retourne et découvre alors, à quelques } \\
\text { mètres, le lieutenant Pradelle qui se rue sur lui en courant aussi vite que lui } \\
\text { permet son harnachement. (24) }\end{array}$ & $\begin{array}{l}\text { Maillard : ?!? Grisonnier... Thérieux. } \\
\text { Merde alors... } \\
\text {... on leur a tiré dans le dos. } \\
\text { Pradelle : Qu'est-ce que vous voulez Maillard, les gars n'étaient pas très } \\
\text { chauds pour attaquer. } \\
\text { Maillard : C'est vous qui... } \\
\text { Pradelle : Pour les foutre en boule... Efficace, non ? (16) }\end{array}$ \\
\hline $\begin{array}{l}\text { Mme Maillard le fixe d'un regard réprobateur, décidément Albert ne saura } \\
\text { jamais s'y prendre, tomber dans un trou, je vous demande un peu, mourir } \\
\text { juste avant la fin de la guerre, passe encore, c'est idiot, mais bon, on peut } \\
\text { comprendre, tandis que mourir enterré, autant dire dans la position d'un } \\
\text { homme déjà mort ! C'est tout lui, ça, Albert, jamais comme les autres, } \\
\text { toujours un peu moins bien (35) } \\
\text { Il pleure toujours, Edouard, et il crie en même temps, tandis que ses bras, } \\
\text { mus par une force qu'il ne maîtrise pas, font le ménage, furieusement, } \\
\text { balayent la terre. La tête du soldat apparait enfin, à moins de trente } \\
\text { centimètres, comme s'il dormait ; il le reconnaît, il s'appelle comment déjà ? } \\
\text { (49) } \\
\text { A grand gestes larges, il achève de dégager le corps. Le nom lui revient : } \\
\text { Maillard. Le prénom, il ne l'a jamais su, on disait seulement Maillard. (50) }\end{array}$ & $\begin{array}{l}\text { (Mme Maillard : Il est comme ça mon Albert. Il fait toujours tout de travers.) } \\
\text { Péricourt : Tiens bon ! C'est Péricourt. Je vais te sortir de là ! } \\
\text { (Mme Maillard : Mourir alors que la guerre est presque terminée.) } \\
\text { Péricourt : Maillard! } \\
\text { Allez ! Respire ! }(20,21)\end{array}$ \\
\hline
\end{tabular}

Književnost putem verbalnog izaziva slike, drugim riječima „slike putem misli“, a strip „izaziva misli pomoću slike" te slikovno po važnosti i učinku nadmašuje verbalno (Munitić 24). Pripovijedanje se u romanu manifestira ili kao kazivanje, komentiranje ili kao opisivanje. Strip pak kao narativ u slikama koristi upravo mogućnosti crteža za opisivanje. Stoga primjerice slikovni prikaz Pradellea (11) može primjereno zamijeniti njegov opis iz romana (ARLH 15; VSTG 12-13). Na posljednjoj vinjeti na stranici 14 koja prikazuje Pradellea on nalikuje vampiru, što je, naravno, slikovna aluzija na njegovu osobnost. Nadalje, stanovite preinake koje se pojavljuju u stripu u odnosu na roman također su usko vezane uz mogućnosti njegova grafičkog izraza. Prvi makrosegment romana govori o zbivanju čije trajanje obuhvaća (maksimalno) nekoliko sati, no ono se u stripu produžava na razdoblje od noći do zore. Tako se od „[u] trenucima koji su slijedili“ u romanu (VSTG 14) vremenska perspektiva u stripu mijenja na „[u] zoru“ (14), kad počinje napad. Promjena 
vremenskog plana u stripu povezana je dakako s konvencijom vrste, borbu bi naime bilo teško prikazati u mraku, a na ovaj način veći je i kontrast u odnosu na tamu u kojoj se Albert našao po zatrpavanju u jami. Slično je i s padom koji je prethodio njegovu zatrpavanju. U romanu Maillard pada u jamu nakon što ga je Pradelle udario ramenom, i to u trku, a u stripu se radi o udarcu nogom koji je u ovom mediju moguće efektnije prikazati. Adaptacije se odnose i na korištenje onomatopeja u stripu, primjerice vinjeta s tri puta ponovljenim „paw“ odgovara naraciji u romanu o zvuku triju metaka koji su pogodili vojnike i tišini koja je zatim nastupila (ARLH 17; VSTG 14). Na vinjetama koje prikazuju borbu brojne su onomatopeje za eksplozije - „baoum“, ispisano većim ili manjim slovima, što je dakako ekvivalent za snagu eksplozije.

Opisujući pripremu za izlazak vojnika iz rova roman donosi dugačak flashback o Maillarovu ranijem Životu na otprilike tri stranice (ARLH 18, 19-22; VSTG 15-17) koji usporava naraciju, dok ga strip u potpunosti izostavlja. Izlazak iz rova prikazan u stripu odgovara opisu iz romana, u kojem pripovjedač govori kako Albert napreduje pognut te primjećuje ranjenog Péricourta (ARLH 22; VSTG 18), što bi odgovaralo 15. stranici stripa, a zatim dolazi do promjene fokalizacije u pretposljednjoj vinjeti čime se sugerira da je upravo Albert taj koji vidi scenu pokolja vojnika, međutim, zbog izbora plana (total) nije sigurno koji je od ranjenih vojnika točno Péricourt. Specifična struktura stripa podrazumijeva pojavljivanje kvadrata-sličice, vinjete kao istovremeno samostalne i dostatne slikovne i informacijske jedinice o određenom trenutku i jediničnom djeliću zbivanja, no istovremeno se sagledava i u kontekstu kompletnog organizma kao funkcionalna karika narativnog lanca uklopljena u montažni niz (Munitić 22). Velika vinjeta na stranici 17 tako primjerice prikazuje Alberta Maillarda u jami, a niz triju manjih postraničnih vinjeta prvo Pradellea kako ga promatra, zatim Alberta u glibu gotovo do struka te napokon Pradellea kako odlazi, čime dolazi do odmaka od linearnog čitanja pasice, od lijevo-desno, dolje-lijevo na lijevo-desno, goredolje. Stranica 18. stripa prikazuje Albertovo zatrpavanje nakon pada neprijateljske granate i Péricourta koji to primjećuje, a u slijedu vinjeta koje prikazuju Alberta pod zemljom i Péricourta koji kopa prikazuje se simultanost radnje. Velika vinjeta preko cijele 19. stranice, čime dolazi do usporavanja stripovske naracije, donosi posljednji Maillardov udah iz konjske glave, te je ondje zapravo ispričan čitav jedan mikrosegment fabule (A1k0 VI. iz romana) ${ }^{[3]} \mathrm{Na}$ idućoj se stranici naracija nastavlja izmjeničnim montiranjem vinjeta koje prikazuju zatrpanog Maillarda kojem se 
pričinjaju majčine riječi, Péricourta koji i dalje kopa te se predstavlja i obraća bratu po oružju pod zemljom, čime se postiže dojam simultanosti. Péricourt napokon izvlači i prepoznaje Maillarda te ga udara rukom ne bi li ga oživio, za razliku od romana, gdje je ustao i cijelom se težinom na njega obrušio. Maillard napokon dolazi k sebi, a u posljednjoj vinjeti ovog segmenta fabule (22) Péricourt biva ranjen, no scena je viđena s leđa, čime se gradi napetost kroz neizvjesnost o njegovoj daljnjoj sudbini.

\section{Zaključak: moć narativa - od umjetnosti riječi do 9. umjetnosti}

Svojstva samog medija, kao materijalnog sredstva izražavanja adaptacije, imaju presudnu ulogu u procesu transkodiranja jednog umjetničkog djela u drugo. Promjena medija naime zahtjeva prilagodbu gramatici i sintaksi novog medija, a poštovanje njegovih formalnih konvencija s jedne strane znači ograničavanje, a s druge otvaranje novih izražajnih mogućnosti u odnosu na prvotni medij uslijed čega adaptacija biva kreativnim procesom. Proces adaptiranja uključuje dakako i odabir onih struktura koje će iz predloška biti prenesene u novo djelo (Hutcheon 33-40). Poredbena naratološka analiza romana i stripa Vidimo se tamo gore pokazuje da pomak od pripovjedačkog k prikazivačkom načinu iskazivanja tako primjerice zahtijeva dramatizaciju u smislu da se pripovijedanje, opisivanje i prenošenje misli prisutno u romanu u stripu transkodira u govor, odnosno dijaloge, crteže odnosno slike, djelovanje likova, zvukove, uz stanovito preinačavanje fabule, fokalizacije, tema i motivacije likova.

Naposljetku se dakako nameće još jedno pitanje, ono vrednovanja adaptacije - kada je adaptacija uspjela? Roman i strip zasebna su umjetnička djela, a vrijednosni se stav o njima ne može izreći u okvirima vjernosti jednog djela drugom, nego funkcioniranja unutar vlastite poetike vrste, zadanih pravila žanra ili intencionalnog poigravanja s njima, odnosno odstupanja od njih. Način na koji će predložak biti adaptiran, kao i sâm proces adaptacije, ovisi dakako o specifičnostima uključenih medija, pri čemu je, kako naglašava Peeters (170), u slučaju stripa dobra suradnja scenarista i crtača kroz koju oni postaju jedno, „treći čovjek“, presudna. Philippe Torreton u predgovoru stripu Au revoir là-haut (9) naglašava upravo uspješnu Lemaitreovu i De Metterovu suradnju - scenarist kvadrate nije preopteretio tekstom, nego se povukao i dao povjerenje crtežima, dok De Metter isto 
tako nije želio „sve prikazati“, čime je u konačnici izbjegnut "građanski rat između riječi i slika“. Drugim riječima, Torreton ističe pravu mjeru u suradnji jer su i scenarist i crtač uspjeli sačuvati upravo one elemente narativa koji omogućavaju nesmetano odvijanje priče te je ovaj strip uspješan plod njihova međusobna uvažavanja. Zamjetno je nadalje da roman Vidimo se tamo gore uspješno spaja visoku i nisku književnost, žanr povijesnog romana s onim trivijalni(ji)m, kriminalističkim, a bez tendencije povlačenja analogija između dvaju medija, da su skraćivanja i preinačivanja fabule u stripu u nekoj mjeri ipak dovela do gubitka napetosti svojstvene krimiću. Moglo bi se stoga izreći relativno žaljenje što strip nije ostao bliži svojim korijenima, odnosno stripu u nastavcima čime bi se znatno pridonijelo održanju konstantne napetosti, te što je propustio priliku u većoj se mjeri poigrati odnosom visokog i niskog žanra.

Napokon, Groensteen (La Bande dessinée Mode d'emploi 56) je s pravom mogao primijetiti da neki intelektualci suočeni sa stripom ostaju konsternirani jer ga zapravo ne znaju čitati. Čitanje stripa naime pretpostavlja postojanje kompetentnog čitatelja, onoga koji poznaje njegov komunikacijski kodeks (Munitić, 34-35), odnosno zna dešifrirati kodove i konvencije svojstvene devetoj umjetnosti. Adaptacija je pak reinvencija, ponovno osmišljavanje izvornika u drugoj formi izraza, iznalaženje u drugom mediju ekvivalenata za forme izraza predloška, vodeći pritom računa o načinu na koji se medij povezuje sa svojom publikom. Preostaje međutim i nešto što bismo mogli nazvati iskonskom moći narativa - narativ je naime moguće promatrati kao dubinsku strukturu neovisnu o samom mediju (Chapman, prema Schröter 3), kao strukturu koja prethodi sintetiziranju medija (Schröter 5-6), a svojstveno mu transkodiranje i dekodiranje omogućuje pomak od umjetnosti riječi k 9. umjetnosti.

\section{Works Cited}

Delobbe, Karine. La bande dessinée. Pemf, 2003.

Genette, Gérard. Figures III. Éditions de Seuil, 1972.

Groensteen, Thierry. La Bande dessinée. Les essentiels Milan, 1997.

Groensteen, Thierry. La Bande dessinée Mode d'emploi. Les Impressions Nouvelles, 2007. Hutcheon, Linda. A Theory of Adaptation. Routledge, 2006. 
Jouve, Vincent. La poétique du roman. Sedes, 1997.

Lemaitre, Pierre. Au revoir là-haut. Editions Albin Michel, 2013.

Lemaitre, Pierre. Vidimo se tamo gore. Prevela Marija Paprašarovski, Vuković \& Runjić, 2015.

Lemaitre, Pierre, i Christian De Metter. Au revoir là-haut. Rue de Sèvres, 2015.

Munitić, Ranko. Strip, deveta umjetnost. Udruga za popularizaciju hrvatskog stripa ART 9, 2010.

Peleš, Gajo. Tumačenje romana. Artresor, 1999.

Peeters, Benoît. Lire la bande dessinée. Flammarion, 2003.

Rajewsky, Irina O. "Intermediality, Intertextuality and Remediation: A Literary Perspective on Intermediality." Intermédialités, vol. 6, 2005, pp. 43-64,

https://www.erudit.org/revue/im/2005/v/n6/1005505ar.pdf. Pristupljeno 12. kolovoza 2018.

Schröter, Jens. "Discourses and Models of Intermediality." CLCWeb: Comparative Literature and Culture, vol. 13, no. 3, 2011, pp.1-7,

https://docs.lib.purdue.edu/cgi/viewcontent.cgi?article=1790\&context=clcweb/. Pristupljeno 12. srpnja 2018.

„Strip“. Hrvatska enciklopedija, http://www.enciklopedija.hr/natuknica.aspx?ID=58410. Pristupljeno 9. kolovoza 2018.

Žmegač, Viktor. Povijesna poetika romana. GZH, 1991. 
[1] U ovom će se radu koristiti skraćenice ARLH za francusku, te VSTG za hrvatsku inačicu Lemaitreova teksta.

[2] Budući da strip još nije prveden na hrvatski, radi boljeg uočavanja srodnosti i odstupanja izvatci iz teksta romana ovdje se navode na francuskom jeziku.

[3] Motiv konjske glave iz jame ponovno se tematizira i kasnije u romanu i stripu. Péricourt će je nacrtati za Maillarda prema njegovu sjećanju i uputama, a zatim mu i izraditi konjsku masku, čime dolazi do zanimljive refleksije dvaju medija te problematiziranja mimetičkog i semiotičkog karaktera crteža u stripu.

\section{(c) $($ ) $(9)$}

Creative Commons Attribution-NonCommercial-NoDerivatives 4.0 International License 